\title{
Iron metabolism in copper-deficient rats
}

\author{
By THE LATE H. R. MARSTON, SHIRLEY H. ALLEN AND S. L. SWABY \\ Division of Nutritional Biochemistry*, \\ Commonwealth Scientific and Industrial Research Organization, \\ University of Adelaide, South Austral. 5000, Australia \\ (Received I8 August 1969-Accepted 7 July 1970)
}

\begin{abstract}
I. The effects of ingestion of diets deficient in both copper and iron on storage of these elements and on the red cell indices have been studied in rats.

2. Injection of $\mathrm{Cu}$ into rats whose stores of $\mathrm{Cu}$ had been virtually exhausted resulted in a temporary increase in the concentration of plasma $\mathrm{Fe}$ and depletion of the Fe stored in the liver. Storage of $\mathrm{Fe}$ in the spleen seemed to be affected somewhat differently from that in the liver.

3. $\mathrm{Fe}$ injected into $\mathrm{Cu}$-deficient rats was transported to storage sites but, although the plasma Fe concentration was presumably transiently increased thereby, there was no lasting effect.

4. The hypotheses that $\mathrm{Cu}$ mediates in the release of $\mathrm{Fe}$ from ferritin and that of Osaki, Johnson \& Frieden (I 966) that caeruloplasmin promotes the rate of Fe-saturation of apotransferrin are discussed.
\end{abstract}

The particular functions which copper assumes in the metabolism of iron have not been greatly clarified during the 40 years since Elvehjem and his co-workers noted that rats given a diet composed solely of milk responded to the administration of $\mathrm{Fe}$ only if $\mathrm{Cu}$ was provided in addition (Hart, Steenbock, Waddell \& Elvehjem, I928).

The following series of experiments was carried out in an attempt to throw some light on the problem. Rats were used as the experimental animals as deficiencies of both $\mathrm{Cu}$ and $\mathrm{Fe}$ may be relatively easily produced in them. A brief report of our findings has appeared (Marston \& Allen, 1967).

\section{EXPERIMENTAL AND RESULTS}

\section{Materials and methods}

Animals. Male rats (Wistar strain) were weaned at 4 weeks of age, placed in individual cages and given ad lib. the milk diet detailed below. The cages for Expt I were of conventional design and made of tinned wire; those for Expt 2 consisted of an anodized aluminium cylinder with a stainless-steel band at the top, to prevent chewing of the edge, and brackets to hold the glass cover-plate. A chromed wire screen formed the bottom of the cage.

Supplements were provided as required for the individual experiments. Oral supplements, to which three drops of a saturated solution of sucrose were added, were offered in syracuse watch glasses. Water for drinking was glass-distilled. The animals were weighed weekly.

Diet. The ingredients were: full-cream powdered milk, $1320 \mathrm{~g}$; sucrose, $595 \mathrm{~g}$;

* Formerly Division of Biochemistry and General Nutrition. 
sodium chloride, $43.5 \mathrm{~g}$; cellulose, $40 \mathrm{~g}$ (filter paper, washed with $0.2 \mathrm{~N}-\mathrm{HCl}$ and water, shredded and made into a pulp with the aid of water and a mechanical stirrer with a stainless-steel spindle and polyethylene blades); cod-liver oil, $7.5 \mathrm{~g}$; mineral mixture, $20 \mathrm{ml}\left(\mathrm{ZnSO}_{4} \cdot{ }_{7} \mathrm{H}_{2} \mathrm{O}, 8.82 \mathrm{~g} ; \mathrm{MnSO}_{4} \cdot{ }_{4} \mathrm{H}_{2} \mathrm{O}, 4.05 \mathrm{~g} ; \mathrm{CoSO}_{4} \cdot 7 \mathrm{H}_{2} \mathrm{O}, 2.4 \mathrm{~g}\right.$; each dissolved separately, mixed and $10 \mathrm{ml} 6 \mathrm{~N}-\mathrm{HCl}$ added before diluting with water to I 1). Water was added to the diet to give a consistency which would drop fairly readily off a spoon.

Sulphided diet was treated with $3 \mathrm{ml}$ of a $15 \%(\mathrm{w} / \mathrm{v})$ solution of sodium sulphide/ $450 \mathrm{~g}$ diet to convert any $\mathrm{Cu}$ in the diet into a form which is unavailable to the rat (Summerson, 1938). The diet was left in a refrigerator, at least overnight, before using.

The diet contained $c .3 \mu \mathrm{g} \mathrm{Cu}$ and $c .4 \mu \mathrm{g} \mathrm{Fe} / \mathrm{g}$ dry weight.

Analytical methods. All glassware was washed in hot chromic acid, soaked in $10 \%$ $\mathrm{HCl}$, and rinsed first with distilled water and then with glass-distilled water.

$\mathrm{Cu}$ in tissues, blood and diet was estimated by complexing with diethyldithiocarbamate after wet digestion. $\mathrm{Cu}$ in plasma was estimated as described by Rice (I 963).

$\mathrm{Fe}$ in tissues was estimated, after wet digestion, by complexing with $\alpha, \alpha^{\prime}$-dipyridyl, using thioglycollic acid as reducing agent. Fe in diet, after wet digestion, and in plasma was estimated by complexing with bathophenanthroline (Giovanniello \& Peters, 1963). The method of Giovanniello \& Peters ( 1963 ) was also used for estimation of total Fe-binding capacity of plasma.

Haemoglobin was estimated by the cyanmethaemoglobin method (Dacie \& Lewis, 1963). Haemoglobin in plasma was estimated by the benzidine reaction (Crosby \& Furth, 1956). Samples in which a degree of haemolysis, detectable by eye, had occurred were discarded. Concentrations of plasma Fe were corrected for Fe arising from haemolysis in Expt 2 but not in Expt 1 .

Packed cell volume was determined after centrifugation for $5 \mathrm{~min}$ in an Adam's micro-haematocrit centrifuge.

Red cell count: blood was diluted with Hayem's solution and the cells were counted in a Neubauer counting chamber.

Extraction and estimation of ferritin. Bone-marrow from four femurs and four tibias was scraped into a micro-beaker containing $c .0 .5 \mathrm{ml}$ of water and the beaker was sealed and stored in a deep-freeze unit. The marrow was subsequently triturated with a glass rod, homogenized in a total volume of $\mathrm{r} \mathrm{ml}$ (made up with $0.03 \mathrm{M}-\mathrm{NaCl}$ ) at $\mathrm{pH} 7 \cdot 0$ and the homogenate centrifuged. The supernatant fraction was heated with stirring for $5 \mathrm{~min}$ in a water bath at $70^{\circ}$, cooled, centrifuged and the supernatant fraction reduced in volume by evaporation under redaced pressure over $\mathrm{P}_{2} \mathrm{O}_{5}$. The residue was made to a convenient volume with water and samples were taken for the separation of ferritin by electrophoresis on cellulose acetate in $0.067 \mathrm{M}$-phosphate buffer at $\mathrm{pH} 6.4$ (Darcel, I961). Ferritin was stained by heating for $15 \mathrm{~min}$ at $56^{\circ}$ in a freshly prepared mixture of equal quantities of $0.2 \mathrm{~N}-\mathrm{HCl}$ and $2 \%(\mathrm{w} / \mathrm{v})$ potassium ferrocyanide solution. The amount of ferritin present in the bone-marrow of a normal rat was estimated quantitatively by spectrophotometric scanning of the appropriately stained cellulose acetate strip and reference to the protein content of the original 
supernatant fraction. The amounts of ferritin present in the marrows of the deficient rats were so small, and consequently the volume that it was necessary to apply to the cellulose acetate was so relatively large, compared with that used for normal rats, that clean separations from the brown contaminating material (haem?) were not possible; assessment was therefore made by visual inspection.

Collection of blood and perfusion: Expt $\mathrm{I}$. Rats were anaesthetized by administration of Nembutal by intraperitoneal injection; a facial mask saturated with diethyl ether was used if an animal showed any sign of returning consciousness. A carotid artery was exposed and freed from connective tissue to allow placing of a micro-clip, to prevent loss of blood during insertion of the cannula, and two lengths of thread. A very small nick was made in the artery with iridectomy scissors and a cannula containing heparin (rooo i.u./ml) was inserted and tied into position. A syringe was attached to the cannula, the clip released and the heparin gently mixed into the circulation. The artery above the cannula was then tied off, the syringe removed and blood collected direct from the cannula into a heparinized tube-about $\mathrm{I}$ o $\mathrm{ml}$ of blood may be obtained from a fully grown rat. To perfuse the animal, the inferior vena cava was cut and $0.9 \%$ saline was passed through the cannula under pressure.

Collection of blood and perfusion: Expt 2. The tail was thoroughly cleaned and the rat was lightly anaesthetized with diethyl ether. As soon as the animal had lost consciousness its tail was placed in a beaker of distilled water at $40^{\circ}$ for $5 \mathrm{~min}$. The tail was dried with paper tissues, a thin coating of petroleum jelly applied to the section to be cut, the tip placed on a glass slide and about $\mathrm{x} \mathrm{cm}$ cleanly removed by cutting with a surgical scalpel blade; a new blade was used for each cut. The tail was held in a vertical position and the blood $(c . \mathrm{I}-\mathrm{I} \cdot 5 \mathrm{ml})$ which dripped from it was collected in a $5 \mathrm{ml}$ conical centrifuge tube which had been coated with paraffin wax and rinsed with water and which contained heparin-three drops of a $1000 \mathrm{i} . \mathrm{u} . / \mathrm{ml}$ solution dried under reduced pressure. Following initial anaesthesia, the rat was kept in a state of semi-consciousness by periodic use of a facial mask saturated with diethyl ether.

A sample of blood $(0.02 \mathrm{ml})$ was removed for estimation of haemoglobin and the remainder spun at a temperature of $60^{\circ}$ to separate the plasma. The most effective way of stopping the bleeding was to slip a rubber O-ring of suitable size on to the tail, so as to restrict the circulation, and leave it in position for $\mathrm{I}-2 \mathrm{~h}$.

Before perfusion, the rat was anaesthetized with Nembutal as described above. The thoracic aorta was exposed and isolated from connective tissue so that a cotton thread could be inserted for tying the cannula into position; heparin $(0.05 \mathrm{ml}$ of $1000 \mathrm{i} . \mathrm{u} . / \mathrm{ml})$ was injected just below the kidneys and time allowed for it to circulate. A cannula was then inserted into the hole made by the needle used for injecting the heparin and tied into position. The greater part of the blood escaped via the cannula which was then connected to a separating funnel containing $0.9 \%$ saline, the artery below the cannula was clipped off with pressure forceps, the inferior vena cava cut and the animal perfused under pressure of $c .55 \mathrm{~cm}$ until the effluent fluid was free of blood. The livers were retained for analysis. 


\section{Expt I. To determine the effects of $(a) C u,(b) \mathrm{Fe}$ and}

(c) $\mathrm{Cu}$ and $\mathrm{Fe}$ deficiencies on rats

Eight groups of rats were chosen from forty-eight animals, divided, on the basis of body-weight (range 68-77 g), into six batches of eight evenly matched rats. Nonsulphided diet (i.e. diet to which sodium sulphide had not been added) was given ad lib. to groups I A to ${ }_{4} \mathrm{~A}$ inclusive; sulphided diet (i.e. diet to which sodium sulphide had been added) was given $a d$ lib. to groups $\mathrm{I} B$ to $4 \mathrm{~B}$ inclusive.

Treatments were as follows: group I (A and B), no supplement; group 2 ( $A$ and $B$ ), $\mathrm{Fe}, 500 \mu \mathrm{g} / \mathrm{d}$, administered orally as $\mathrm{FeSO}_{4}$ in $0.5 \mathrm{ml}$ of solution thrice a week; group 3 ( $\mathrm{A}$ and $\mathrm{B}$ ), $\mathrm{Cu}, 25 \mu \mathrm{g} / \mathrm{d}$, administered by intraperitoneal injection as $\mathrm{CuSO}_{4}$ in $0.25 \mathrm{ml}$ of solution thrice a week; group 4 (A and B), $\mathrm{Fe}, 500 \mu \mathrm{g} / \mathrm{d}$ orally, plus $\mathrm{Cu}, 25 \mu \mathrm{g} / \mathrm{d}$ parenterally, as described for groups 2 and 3 .

After 8 weeks on this regimen blood was collected from each rat and the animals were perfused as described on p. 17. Results of the analyses on blood and tissues are reported in Tables $\mathrm{I}$ and 2.

\section{Expt 2. To determine the effects of parenterally administered $\mathrm{Cu}$ and $\mathrm{Fe}$ on rats given a diet deficient in both $\mathrm{Cu}$ and $\mathrm{Fe}$}

This experiment was made up of a number of parts in each of which the rats were divided initially into two groups: one (deficient), members of which received no supplement, and one (positive control), whose members were given daily $0.5 \mathrm{ml}$ of a supplement that provided $100 \mu \mathrm{g} \mathrm{Cu}+500 \mu \mathrm{g}$ Fe. The stock solution was prepared as follows: $\mathrm{CuSO}_{4} \cdot{ }_{5} \mathrm{H}_{2} \mathrm{O},{ }_{5} 56 \mathrm{mg} ; \mathrm{FeSO}_{4} \cdot 7 \mathrm{H}_{2} \mathrm{O}, \mathrm{I} \mathrm{g}$; ammonium citrate, I $\mathrm{g} ; \mathrm{HCl}$, $\mathrm{I} \cdot 55 \mathrm{ml}$ of $6-\mathrm{N}$; the $\mathrm{pH}$ was adjusted to $c .4$ with $\mathrm{NH}_{4} \mathrm{OH}$ and the mixture diluted to $200 \mathrm{ml}$ with water. Non-sulphided diet was given ad lib. Graphs of mean body-weights, typical for the experiment, are shown in Fig. $\mathrm{I}$.

Meticulous care during the preparation of diet and in the washing of apparatus decreased the period required to produce terminal symptoms of the deficiency from 8 (cf. Expt I) to $4 \cdot 5^{-6}$ weeks.

Effect of $\mathrm{Cu}$. When the animals that had not received the supplement were in an advanced stage of the deficiency syndrome they were divided, as evenly as possible, according to extent of depigmentation and reduction in rate of growth, into the required number of groups. Blood was obtained from the tail of each animal, after which each was treated by intraperitoneal injection with either $\mathrm{Cu}, 200 \mu \mathrm{g}$ in $0.25 \mathrm{ml}$ of a solution of $\mathrm{CuSO}_{4}$ in $0.9 \% \mathrm{NaCl}$, or the same volume of $0.9 \% \mathrm{NaCl}$. After an appropriate interval a second sample of blood was obtained from the tail. The animals were then perfused and the livers removed and retained for analysis.

Following parenteral administration of $\mathrm{Cu}$ to deficient rats, significant increases occurred in the concentrations of plasma Fe compared with those observed after injection of physiological saline (Table 3 ). Two hours after the injection the difference between the mean differences, after and before injection, was significant at $P<0.05$ by the $t$ test; at $\mathrm{I} 8 \mathrm{~h}$ and $24 \mathrm{~h}$ it was significant at $P<0.0 \mathrm{I}$ and $P<0.05$, respectively, both by the $d$ test. 


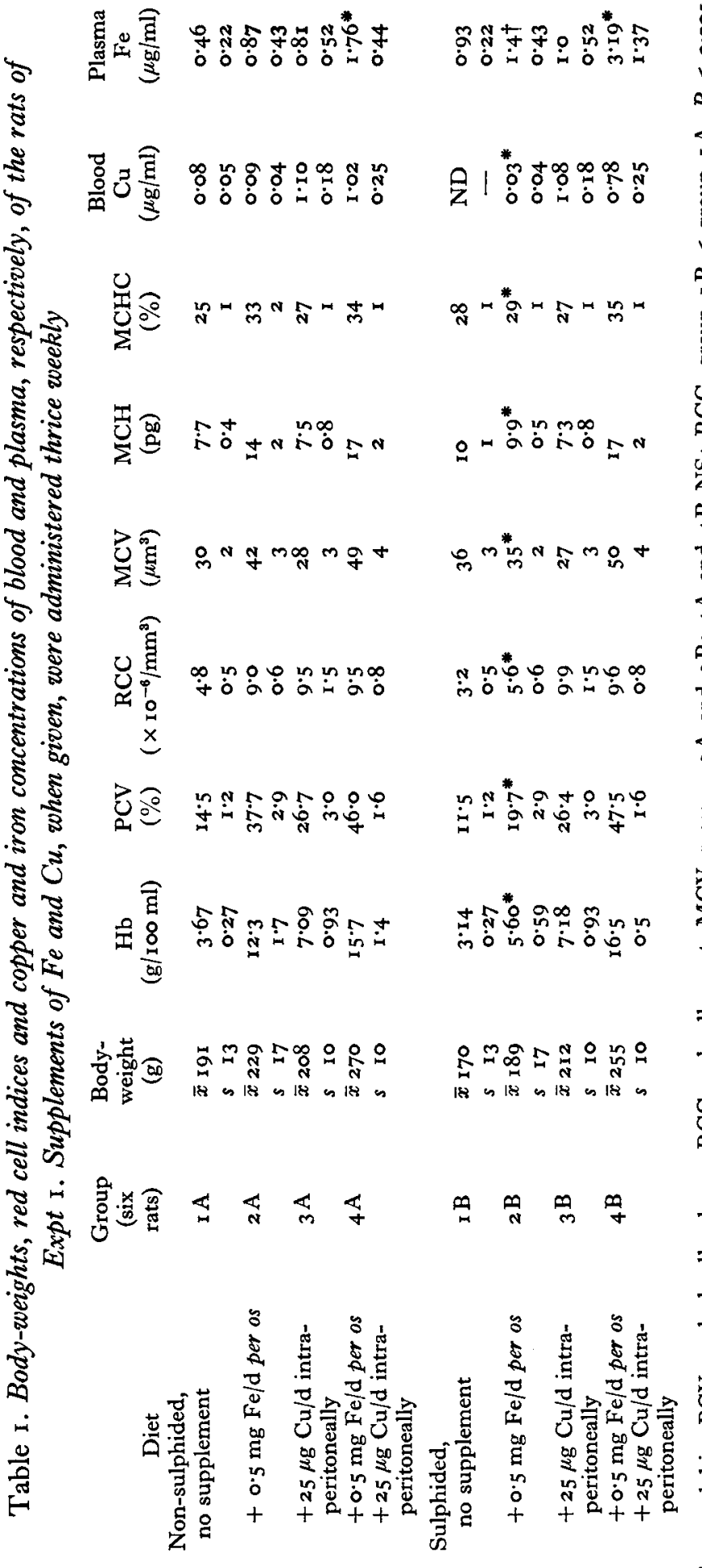

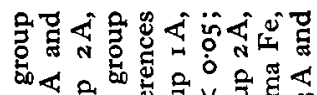

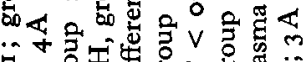

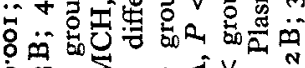

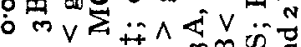

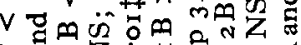
Q.

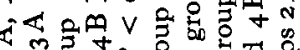

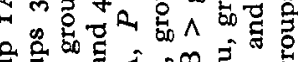

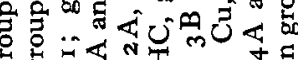

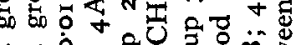
$\checkmark$ 屈

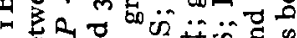

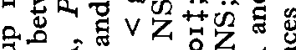

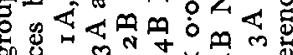
is

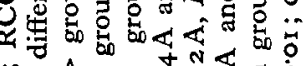

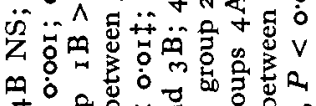
V

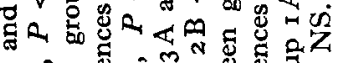

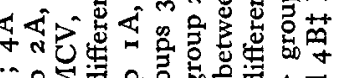

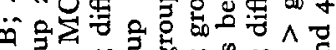

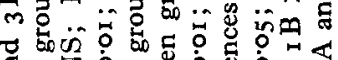

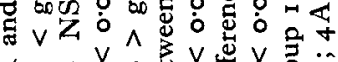

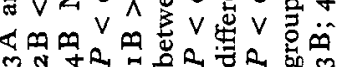

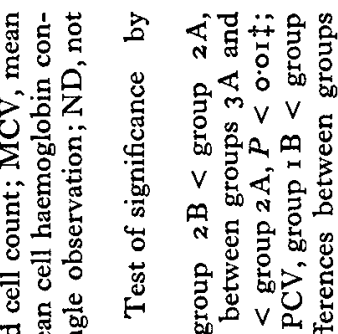

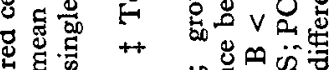

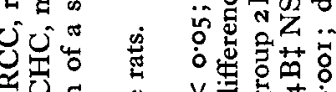

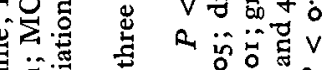

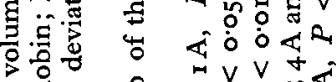

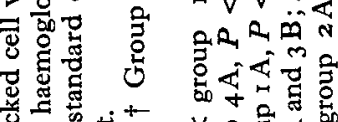
然的崖 v

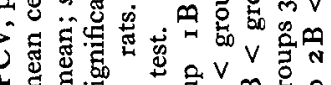
을

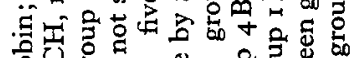

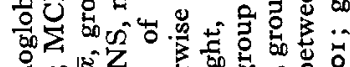

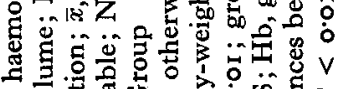

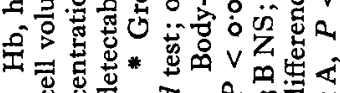




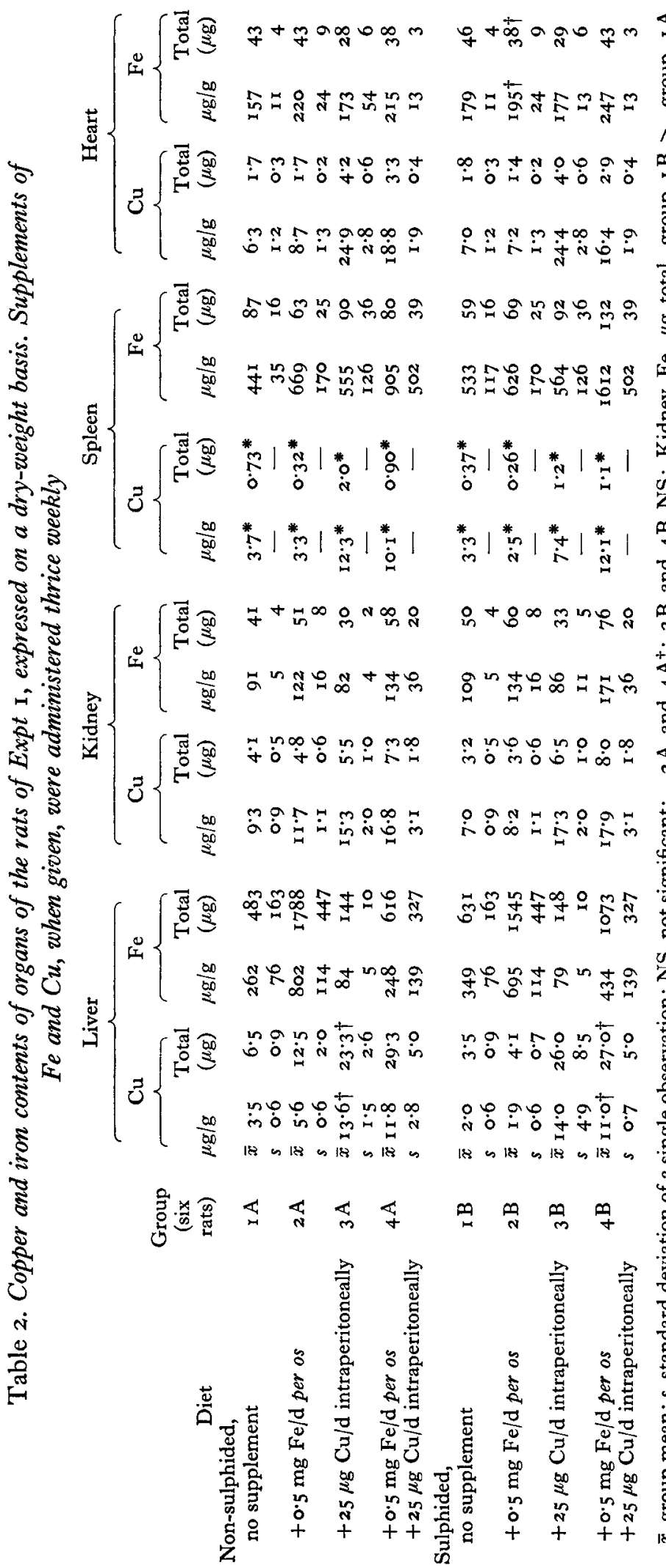

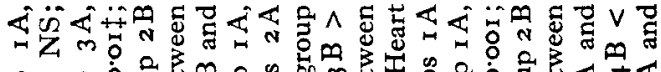

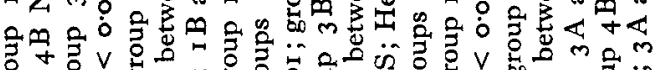
它部人

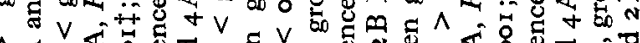

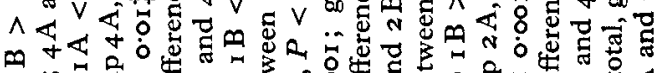

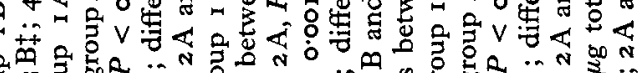

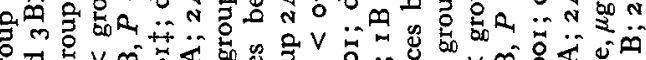

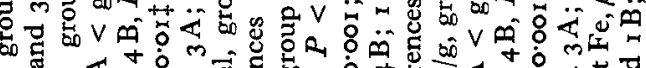

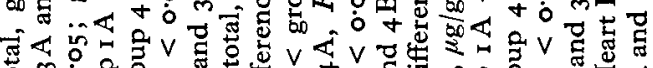

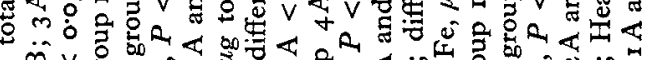

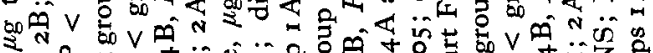

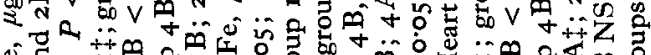

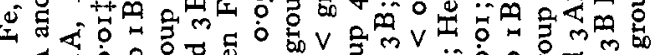

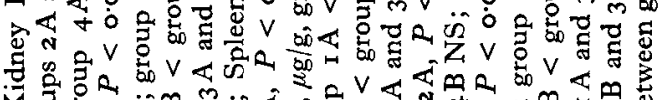

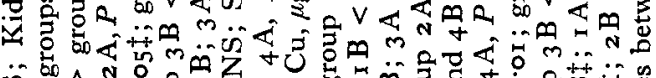

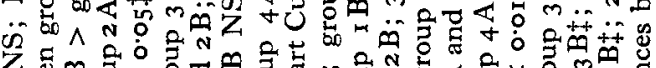

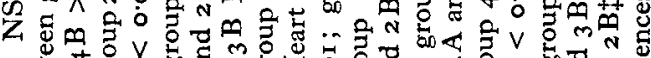

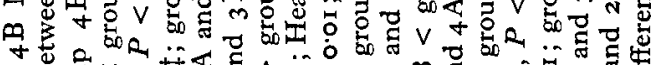

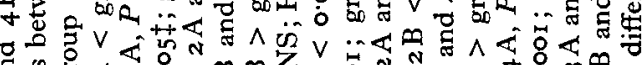
ส

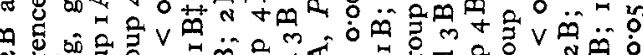

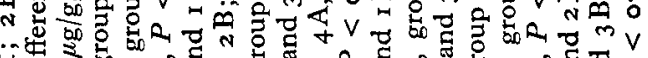
+

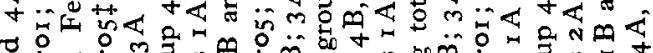

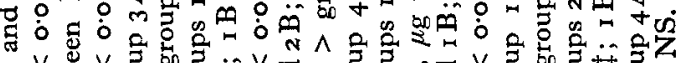

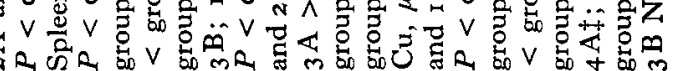

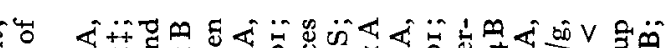

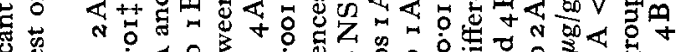

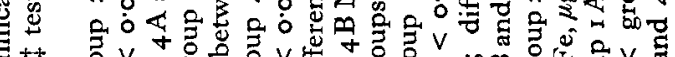

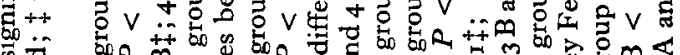

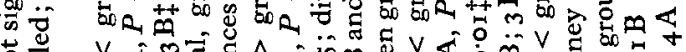

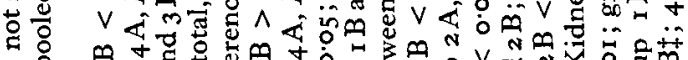
in

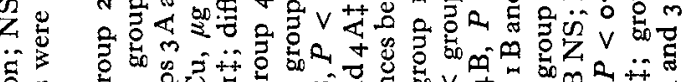

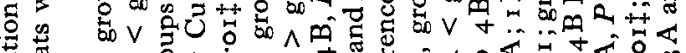
政 \&

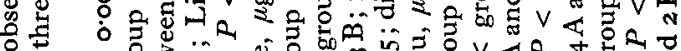

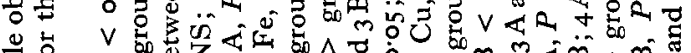
bo Q

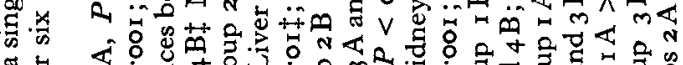

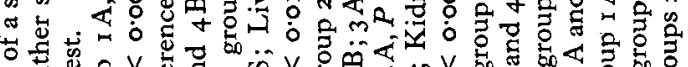

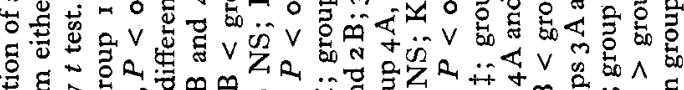

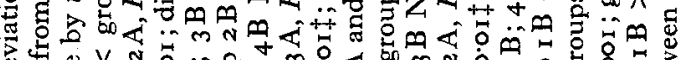

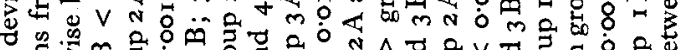

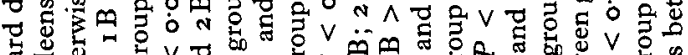

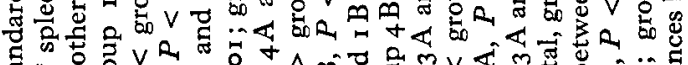
क

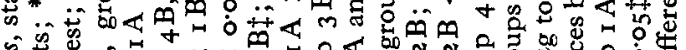

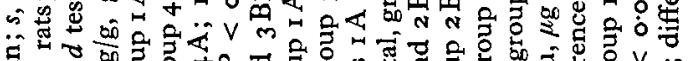

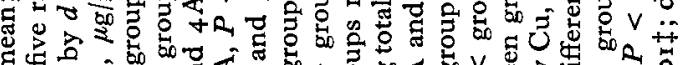

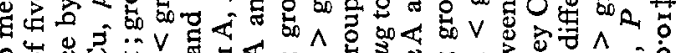

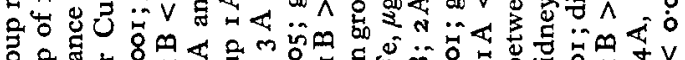

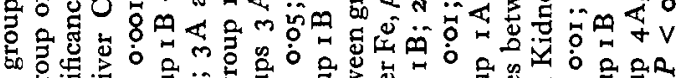

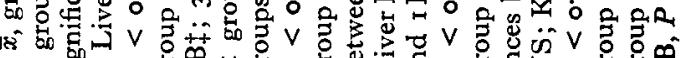
- 
The increases in the concentrations of plasma Fe that occurred 6,12 and $18 \mathrm{~h}$ following injection of $\mathrm{Cu}$ were similar and much greater than that observed $2 \mathrm{~h}$ after treatment. Twenty-four hours after injection the increase was significant but results between experiments were more variable, and $48-72 \mathrm{~h}$ after treatment concentrations of plasma $\mathrm{Fe}$ were not significantly different from those before treatment (Table 4 ). Concentrations of haemoglobin were, in general, lower after than before injection (Table 4 ).

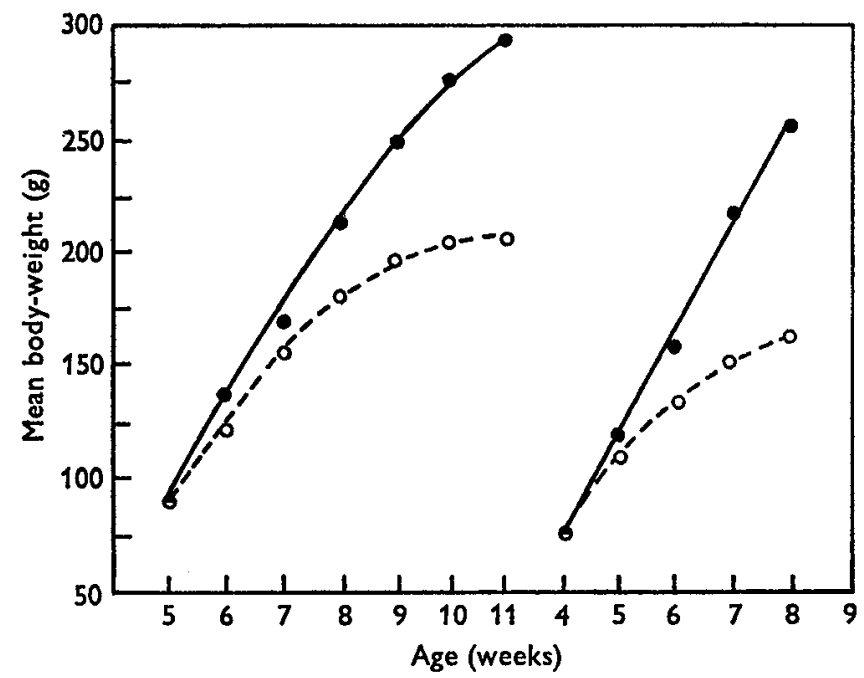

Fig. I. Mean body-weights of rats given a diet deficient in $\mathrm{Cu}$ and $\mathrm{Fe}(\mathrm{O})$ and of the positive control animals (O) during Expt 2.

Table 3. Effect on the concentrations of plasma iron of parenteral administration of copper to rats given a diet deficient in $\mathrm{Cu}$ and $\mathrm{Fe}$

(Mean values and standard deviations of a single difference, with numbers of observations in

\begin{tabular}{|c|c|c|c|c|}
\hline \multirow[b]{3}{*}{ Treatment } & \multirow{3}{*}{$\begin{array}{l}\text { Time } \\
\text { interval } \\
\text { after } \\
\text { injection } \\
\text { (h) }\end{array}$} & \multicolumn{2}{|c|}{ parentheses) } & \multirow[b]{3}{*}{ SD } \\
\hline & & \multicolumn{2}{|c|}{ Plasma Fe $(\mu \mathrm{g} / \mathrm{ml})$} & \\
\hline & & $\begin{array}{c}\text { Pre- } \\
\text { injection }\end{array}$ & $\begin{array}{c}\text { Post- } \\
\text { injection }\end{array}$ & \\
\hline $\mathrm{Cu} *$ & 2 & 0.25 & $0 \cdot 29$ & $0.06(4)$ \\
\hline $\mathrm{NaCl} \uparrow$ & 2 & $0.4 \mathrm{I}$ & 0.33 & $0.06(4)$ \\
\hline $\mathrm{Cu}^{*}$ & I8 & O.I9 & 0.56 & $0.17(12)$ \\
\hline $\mathrm{NaCl} \dagger$ & 18 & 0.26 & $0 \cdot 28$ & $0.10(15)$ \\
\hline $\mathrm{Cu}^{*}$ & 24 & 0.21 & 0.52 & $0.24(9)$ \\
\hline $\mathrm{NaCl} \dagger$ & 24 & 0.26 & 0.32 & $0.09(8)$ \\
\hline
\end{tabular}

Concentrations of both plasma $\mathrm{Fe}$ and haemoglobin of rats in the positive control groups $\mathrm{I} 8$ and $24 \mathrm{~h}$ after injection of $\mathrm{Cu}$ were either not significantly different from or lower than those before injection.

The pre-injection mean concentrations and standard deviations of a single observa- 


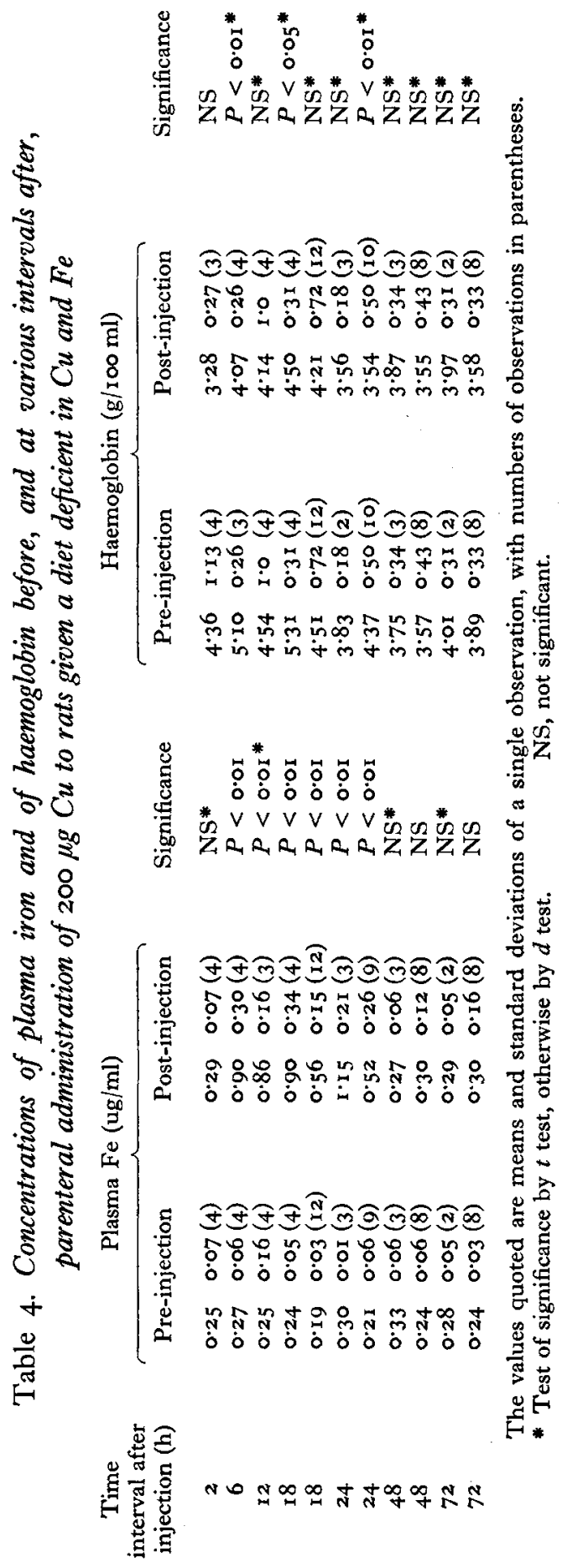


tion, with numbers of rats in parentheses, were: plasma $\mathrm{Fe}$, in $\mu \mathrm{g} / \mathrm{ml}$ : deficient, $0 \cdot 26$, 0.09 (I I3); positive controls, $2.40,0.84$ (I7); and haemoglobin, in $\mathrm{g} / \mathrm{ro0} \mathrm{ml}$ : deficient, $4 \cdot 25,0 \cdot 74$ (109); positive controls, $14 \cdot 6,1 \cdot 0(20)$.

There was no indication of impairment of Fe-binding capacity in the plasmas of deficient rats.

Concentrations of $\mathrm{Cu}$ in the plasmas of deficient rats ranged from undetectable to $<0.05 \mu \mathrm{g} / \mathrm{ml} ; 18,48$ and $72 \mathrm{~h}$ after injection of $\mathrm{Cu}$ the averages and standard deviations of a single observation, with numbers of animals in parentheses, were, respectively, $0.67,0.12(\mathrm{I} 3) ; \mathrm{I} \cdot 06,0 . \mathrm{I} 6(8)$ and $\mathrm{I} \cdot 42,0.50(8)$.

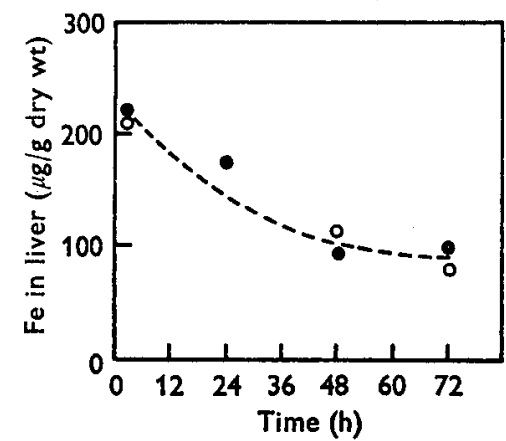

Fig. 2

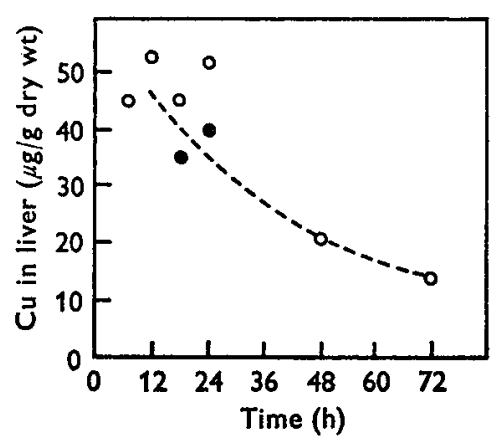

Fig. 3

Fig. 2. Reduction in the concentration of iron in the livers ot rats given a diet deficient in $\mathrm{Cu}$ and $\mathrm{Fe}$ following intraperitoneal injection of $200 \mu \mathrm{g} \mathrm{Cu}$ at $\circ \mathrm{h}$. The points plotted represent two experiments, and each point is the mean value of the concentrations of at least two livers.

Fig. 3. Reduction in the concentration of copper in the livers of rats following intraperitoneal injection of $200 \mu \mathrm{g} \mathrm{Cu}$ at $\circ \mathrm{h}$. The points plotted are the mean values of the concentrations of at least three livers. $\bigcirc$, rats given a diet deficient in $\mathrm{Cu}$ and $\mathrm{Fe} ; \boldsymbol{\odot}$, positive control rats.

Fe stores in the livers of deficient rats gradually became depleted after administration of $\mathrm{Cu}$ (Fig. 2). Eighteen and $24 \mathrm{~h}$ after injection of $\mathrm{Cu}$, mean concentrations of $\mathrm{Fe}$ in the livers of these animals were significantly less $(P<0.01$ and $P<0.001$, respectively, both by the $t$ test) than those of similar rats injected with physiological saline.

Concentrations of $\mathrm{Cu}$ in the livers of both deficient and normal rats rose to abnormally high levels following the injection of $\mathrm{Cu} ; 7^{2} \mathrm{~h}$ later, however, the concentrations in deficient animals approximated to those found in the uninjected, positive controls (Fig. 3). The means and standard deviations of a single observation (with numbers of rats in parentheses) of $\mathrm{Cu}$ concentration in the liver $(\mu \mathrm{g} / \mathrm{g}$ dry weight) were, for deficient rats, $3 \cdot \mathrm{I}$ I, I.IO (39) and for positive controls $\mathrm{I} 3 \cdot 8,3 \cdot \mathrm{I}(6)$.

Release of $\mathrm{Fe}$ in vitro. The animals used for this experiment were perfused with icecold Ringer-phosphate solution, the livers removed, blotted with acid-washed filter paper, placed in containers and transferred to a cold room where slices (c. I g/incubation) were cut as described by Deutsch ( 1936 ) and placed in $5 \mathrm{ml} \mathrm{Krebs} \mathrm{bicarbonate}$ mixture (without phosphate). Anaerobic $\left(95 \% \mathrm{~N}_{2}, 5 \% \mathrm{CO}_{2}\right)$ and aerobic $\left(95 \% \mathrm{O}_{2}\right.$, $5 \% \mathrm{CO}_{2}$ ) incubations ( $\mathrm{I}$ h at $3^{\circ}$ ) were carried out, with shaking, with slices from each liver. At the end of $\mathrm{I} h$ the incubation medium was freed from solid particles by 
centrifugation and $\mathrm{Fe}$ was estimated in the supernatant fraction after precipitation of proteins with trichloroacetic acid; a small sample of the supernatant fraction was retained for estimation of haemoglobin by the benzidine reaction.

The amount of Fe released into the medium during anaerobic incubation of slices of liver, less that released during aerobic incubation, seemed to bear little relationship to their $\mathrm{Cu}$ content; there was, however, a significant linear regression $(P<0.00 \mathrm{I})$ between the concentration of $\mathrm{Fe}$ and that released during incubation.

\section{Table 5. Comparison of the concentrations of iron in livers of rats with the amounts released during anaerobic incubation}

(Mean values and standard deviations of a single observation, with numbers of rats in parentheses)

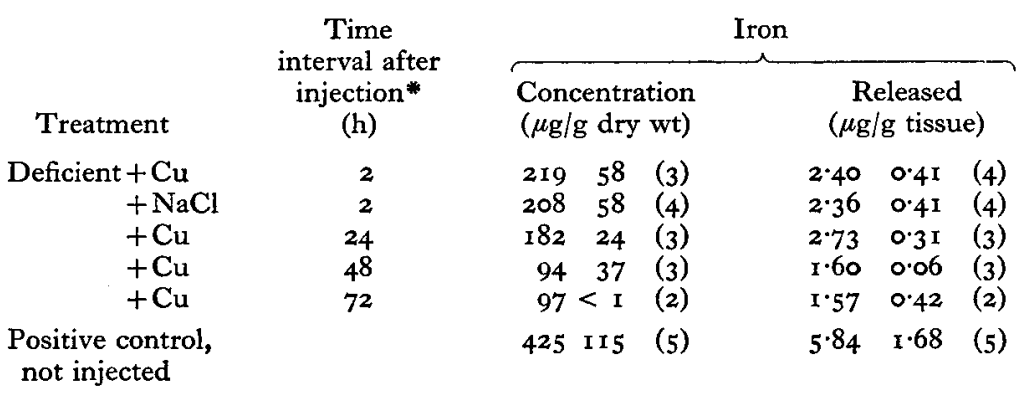

* At which rat killed.

Treatment with copper and $\mathrm{NaCl}$ was by administration of $200 \mu \mathrm{g}$ and $2.25 \mathrm{mg}$, respectively, each by intraperitoneal injection. For details of incubation see p. 23.

Table 6. Concentrations of copper and iron in livers of $\mathrm{Cu}$-deficient and control rats and in $\mathrm{Cu}$-deficient rats injected with $\mathrm{Fe}$

(Mean values and standard deviations of a single observation, with numbers of rats in parentheses)

\section{Group}

A, deficient

$\mathrm{B}$, as $\mathrm{A}+\mathrm{Fe}$

$C$, as $A, 6 d$

later

Positive control

\begin{tabular}{ccc}
\multicolumn{4}{c}{$\mathrm{Cu}$} \\
$(\mu \mathrm{g} / \mathrm{g}$ dry & $\mathrm{wt})$ \\
3.45 & 0.75 & $(6)$ \\
2.42 & 0.35 & $(8)$ \\
$2 \cdot 49$ & $0.7 \mathrm{I}$ & $(\mathrm{II})$ \\
& & \\
$13 \cdot 8$ & $3 \cdot 1$ & $(6)$
\end{tabular}

\begin{tabular}{ccc}
\multicolumn{4}{c}{ Fe } \\
$(\mu \mathrm{g} / \mathrm{g}$ dry & wt $)$ \\
161 & 27 & $(6)$ \\
397 & 72 & $($ IO) \\
207 & 58 & (I I) \\
339 & 54 & $(6)$
\end{tabular}

$1750 \mu \mathrm{g}$ of Fe were administered parenterally to the rats of group B over a period of $5 \mathrm{~d}$.

The amount of $\mathrm{Fe}$ released in vitro $2 \mathrm{~h}$ after injection of $\mathrm{Cu}$ into the live animal was not significantly different (by the $t$ test) from that released during incubation of slices of liver from rats injected with saline. There was no significant difference (by the $t$ test) between the mean concentrations of $\mathrm{Fe}$ in the livers of the two groups (Table 5).

Effect of Fe. At the beginning of the $5^{\text {th }}$ week of this experiment blood samples and livers were taken from six deficient rats (group $A$ ) and ten others were injected with $\mathrm{Fe}$ (group B). A total of $175^{\circ} \mu \mathrm{g} \mathrm{Fe}$ was injected into the peritoneal cavity of each rat in three equally divided doses in $0.25 \mathrm{ml}$ of solution on 3 alternate d; the $\mathrm{Fe}$ was in 
the form of ferrous sulphate and the solution contained $0.1 \%(w / v)$ ammonium citrate.

Twenty-four hours after the third injection, blood samples and livers were obtained from these rats and from eleven deficient rats (group C) from the same experiment.

No significant differences in the mean concentrations of plasma $\mathrm{Fe}$ or haemoglobin occurred between groups $\mathrm{A}, \mathrm{B}$ or $\mathrm{C}$; the concentrations of $\mathrm{Fe}$ in the livers of the rats of group B were, however, increased to normal by parenteral administration of $\mathrm{Fe}$.

The mean concentration of $\mathrm{Cu}$ in the livers of the rats of group $\mathrm{A}$ was significantly higher than those of the groups (B and $\mathrm{C})$ killed $6 \mathrm{~d}$ later $(P<0.05$ by the $d$ test and $t$ test respectively) (Table 6).

Ferritin in bone-marrow. So little ferritin was present in the bone-marrows of deficient rats that it was not possible to detect whether changes in concentration resulted from injection of the animals with $\mathrm{Cu}$. The amount of ferritin in the bone-marrows of rats injected with $\mathrm{Fe}$ (group $\mathrm{B}$ above) was certainly greater than that in those not so injected, although still very much less than that in normal animals.

The greater part of the material which stained with ferrocyanide after electrophoresis of extracts of bone-marrow from deficient rats either remained on the starting line or migrated only a short distance-very little was found in the position assumed by ferritin extracted from the spleen. Whether the material was in fact ferritin whose rate of migration had been altered by the presence of abnormally high concentrations of other materials or whether it was indicative of 'ageing' (a similar phenomenon developed in extracts of ferritin which had been stored for some months in a refrigerator) or whether it was another Fe-containing compound was not determined. Two molecular forms of ferritin have been reported to occur in bone-marrow (Alfrey, Lynch \& Whitley, 1967; Gabuzda \& Pearson, r 968), and an Fe-containing precursor, other than ferritin, has been described by a number of workers (cf. Salera, Magnanelli, d'Avino, Zecca \& Matcovich, I96I ; Greenough, Peters \& Thomas, r962; Zail, Charlton, Torrance \& Bothwell, I964); according to the first-mentioned group, however, the compound does not react with ferrocyanide to form a blue compound. Migration of ferritin extracted from the bone-marrows of rats in the positive control group was similar to that extracted from the spleen, although the material had been stored for the same length of time as that from the deficient animals.

The spleen, under conditions of anaemic stress, may become a site of extramedullary haemopoiesis and the spleens of all of the deficient animals were slightly larger than normal. In the last of this series of experiments the spleens of $25 \%$ of the deficient rats were grossly enlarged. No significant difference between the mean growth rate of these animals and that of the rest of the group was observed; however, the appearance of a histological section was suggestive of a non-specific inflammation.

\section{DISCUSSION}

The symptoms suffered by Cu-deficient animals have been described (Marston, 1952; Underwood, 1962). The first signs of the deficiency to appear in rats are depigmentation of both hair and teeth, harshness of the hair, decrease in the rate of 
growth and anaemia. Depigmentation of the enamel of the teeth, which is known to contain $\mathrm{Fe}$ (Reith, I96I), was very marked in animals deficient in both $\mathrm{Cu}$ and $\mathrm{Fe}$. In the terminal stages, oedema is a particularly noticeable feature, especially in older rats, although we have observed it in animals at 8 weeks of age. Oedema was apparent in only a few of the deficient rats in this series.

The mechanisms by which $\mathrm{Fe}$ is absorbed, becomes attached to apotransferrin and is subsequently transferred to apoferritin at storage sites, and is again mobilized as need arises, have interested research workers over many years (e.g. Beutler, Fairbanks \& Fahey, 1963; Brown, 1963; Harris, 1963; Coons, 1964; Gross, 1964; Smith, Drysdale, Goldberg \& Munro, I968; Wynter \& Williams, 1968).

Saltman and his collaborators have made a critical approach to the problem and, in recently published work (Bates, Billups \& Saltman, r967a, $b$; Billups, Pape \& Saltman, 1967; Pape, Multani, Stitt \& Saltman, I968 $a, b$ ), propose mechanisms which offer more logical and satisfactory explanations of these phenomena than any put forward formerly. They suggest that Fe enters the cell in the form of chelates produced by the binding of ferrous or ferric Fe with low molecular weight chelating agents of exogenous or endogenous origin. Once in the cell the $\mathrm{Fe}$ is either exchanged with other low molecular weight ligands or is bound in a storage form to macromoles such as apoferritin. Attachment of $\mathrm{Fe}$ to apotransferrin and release of Fe from transferrin are thought to be mediated by formation of a ternary complex of a low molecular weight chelator, Fe and apotransferrin, which breaks down to form chelator and transferrin, both reactions being reversible. Confirmation of some of these findings may be found in the work of Aisen, Aasa, Malmström \& Vänngård (I967).

$\mathrm{Cu}$ may influence the metabolism of $\mathrm{Fe}$ in one or more of a number of ways of which the following are relevant: ( 1 ) binding to apotransferrin; (2) release from transferrin; (3) acceptance by apoferritin; (4) release from ferritin; (5) utilization, either direct or indirect, in any one of the innumerable functions of $\mathrm{Fe}$ in the body. Acceptance by apoferritin or apotransferrin, and release from transferrin are unlikely to be involved, for both in Cu-deficient rats (cf. Table 2) and in sheep (Marston, 1952) storage of $\mathrm{Fe}$, provided $\mathrm{Fe}$ is available in the diet, is increased, and in rats (this paper) and sheep (Allen, 1956) the concentration of plasma Fe is decreased, while the total Fe-binding capacity remains unimpaired.

$\mathrm{Fe}$ injected into the peritoneal cavity is thought to be transported via the lymphatics and delivered to the venous circulation through the thoracic duct (Hedenstedt, 1947; Thirayothin \& Crosby, I962). A considerable proportion of the Fe injected into rats subsisting on a diet deficient in $\mathrm{Cu}$ and $\mathrm{Fe}$ reached the liver, for the concentration was thereby approximately doubled compared with that in rats not so injected (Table 6), and some was transported to the bone-marrow. The concentrations of $\mathrm{Cu}$ in the plasmas of these animals ranged from undetectable to $0.05 \mu \mathrm{g} / \mathrm{ml}$, a range some ten times lower than that reported by Dreosti \& Quicke (I968) for rats allegedly $\mathrm{Cu}$-deficient. Osaki, Johnson \& Frieden (I966) postulate a catalytic role for caeruloplasmin in converting ferrous into ferric $\mathrm{Fe}$, thereby promoting its rate of incorporation into apotransferrin. If the intraperitoneally injected $\mathrm{Fe}$ was in fact transported by transferrin then either caeruloplasmin is not essential for incorporation of $\mathrm{Fe}$ into 
transferrin or the amount required is extraordinarily small. Transferrin apparently functioned normally in the Cu-deficient rats under study, for the amount of $\mathrm{Fe}$ associated at any one time with transferrin, at least in the healthy animal, is small compared with the amount transported each day (Harris, 1963; Cheney, Lothe, Morgan, Sood \& Finch, 1967). The release of Fe from ferritin and its subsequent utilization should therefore be considered in seeking the functions of $\mathrm{Cu}$ in the metabolism of $\mathrm{Fe}$.

The values quoted in Table $\mathrm{I}$ for concentrations of plasma Fe were not corrected for $\mathrm{Fe}$ arising from haemolysis; not so much reliance can be placed on them, therefore, as on those quoted in subsequent tables; however, it is clear that, in the groups to which no supplements were administered, concentrations of plasma Fe were lower and of haemoglobin higher in animals given the non-sulphided diet (group r A) than in those (group I B) on the sulphided diet-the diet in which the small amount of $\mathrm{Cu}$ present had been rendered unavailable. Comparison of the groups supplemented with $\mathrm{Fe}$ (groups $2 \mathrm{~A}$ and $2 \mathrm{~B}$ ) shows again that haemoglobin concentrations were higher in the animals that consumed the non-sulphided diet, indicating greater availability of $\mathrm{Fe}$ in those animals in which the concentration of $\mathrm{Cu}$ was less limited.

Packed cell volume was influenced by the relative deficiencies of $\mathrm{Cu}$ and $\mathrm{Fe}$ in a manner very similar to that of haemoglobin. The effects of the deficiencies on the other red cell indices are less clear; they confirm, however, findings from many laboratories that the anaemias produced are microcytic in nature.

Concentrations of $\mathrm{Fe}$ in the storage organs, liver and spleen, were affected differently by the relative deficiencies of $\mathrm{Fe}$ and $\mathrm{Cu}$ (Table 2). The concentrations of $\mathrm{Fe}$ in the spleens of the animals supplemented with $\mathrm{Cu}$ (group 3 ) were either not significantly different from, or greater than those of the unsupplemented animals (group I). In the livers, on the other hand, concentrations of $\mathrm{Fe}$ were highly significantly lower in the animals given the $\mathrm{Cu}$ supplement compared with those on the unsupplemented basal diet. There is apparently a concentration of $\mathrm{Fe}$ in the liver of rats, $c .80 \mu \mathrm{g} \mathrm{Fe} / \mathrm{g}$ dry weight, below which it is impossible for the animal to exist. This was the concentration to which the livers of the animals of group 3 (Table 2) were reduced and the concentration approached in deficient rats of Expt 2, 72 $\mathrm{h}$ after they had been injected with $\mathrm{Cu}$ (Fig. 2).

Concentrations of $\mathrm{Fe}$ in the spleens of rats given a supplement of Fe (group 2) were significantly higher than those in the animals not given the supplement only in those on the non-sulphided diet, whereas storage in the liver was increased in both groups $2 \mathrm{~A}$ and $2 \mathrm{~B}$ compared with that in the groups not given the supplement. The relatively small amount of $\mathrm{Fe}$ found in the spleen, even in the control animals, indicates that it is derived from the haemoglobin of aged red cells and that this organ contains little of the Fe absorbed direct from the intestinal tract. It is possible that Fe is stored in the spleen in a different form from that in the liver, or that its release is effected by a different mechanism, or that the concentration in the spleens of the deficient rats represented a minimum below which the animals could not survive; whatever the reason, the availability of $\mathrm{Cu}$ did not have the same dramatic effect on storage of $\mathrm{Fe}$ in the spleen that it did on that in the liver. Reduction, induced by 
haemorrhage, of $\mathrm{Fe}$ stored in the livers and spleens of rats has, on the other hand, been reported (Morgan, $196 \mathrm{I}$ ) to occur in the same relative proportions from these organs.

In the kidney, as in the liver, concentrations of $\mathrm{Fe}$ were lower in the groups supplemented with $\mathrm{Cu}$. In the heart, in which $\mathrm{Fe}$ is probably associated primarily with enzyme systems and myoglobin, comparison of concentrations between the various groups, without dissection into the constituents, is less meaningful than where storage $\mathrm{Fe}$ is considered.

Concentrations of $\mathrm{Cu}$ were significantly decreased in liver, kidney and heart of basal, compared with positive control groups. It is not immediately apparent why the concentrations of $\mathrm{Cu}$ in all three organs of the rats on the non-sulphided diet should be less in the basal than in the group given the Fe supplement, or why, on both diets, the concentrations of $\mathrm{Cu}$ in the hearts of the animals given a supplement only of $\mathrm{Cu}$ should be higher than those of the groups given supplements of both $\mathrm{Cu}$ and $\mathrm{Fe}$.

Further support for the hypothesis that $\mathrm{Cu}$ is needed for the release of $\mathrm{Fe}$ was obtained during the course of Expt 2. Injection of $\mathrm{Cu}$ into deficient rats was followed by a significant increase in the concentration of plasma Fe compared with that in rats injected with physiological saline solution (Table 3 ).

The increase in the concentration of plasma Fe that occurred in deficient animals 2-24 $\mathrm{h}$ after treatment with $\mathrm{Cu}$ and removal of a small quantity of blood may indicate that the $\mathrm{Fe}$ so released cannot immediately be utilized efficiently for production of haemoglobin. Similar treatment of control animals was followed either by a decrease, or a non-significant increase, of plasma $\mathrm{Fe}$, indicating rapid utilization to replace the haemoglobin lost by bleeding. At least $20 \%$ of labelled Fe injected into normal rats may be detected in the red cells within $24 \mathrm{~h}$ (cf. Reichlin \& Harrington, r960).

Although, 48 and $72 \mathrm{~h}$ after a single injection of $200 \mu \mathrm{g}$ of $\mathrm{Cu}$ into deficient rats, the concentrations of plasma $\mathrm{Fe}$ were not significantly different from those before injection (Table 4 ), Fe continued to be released from the liver throughout the period of observation (Fig. 2), from which it may be tentatively concluded that following treatment with $\mathrm{Cu}$ a period of more than $24 \mathrm{~h}$ was needed for efficient utilization of the Fe released into the circulation.

Injected $\mathrm{Cu}$ was transported fairly rapidly to the livers of deficient rats (Fig. 3) and, unlike $\mathrm{Fe}$, the concentration in the plasma gradually increased over the following $72 \mathrm{~h}$.

$\mathrm{Fe}\left(\mathrm{I} 75^{\circ} \mu \mathrm{g}\right)$ injected into the peritoneal cavities of $\mathrm{Cu}$-deficient rats over a period of $5 \mathrm{~d}$ had no apparent influence, $24 \mathrm{~h}$ after the last injection, on the concentrations of either plasma $\mathrm{Fe}$ or haemoglobin; the concentration of $\mathrm{Fe}$ in the liver was, however, increased to normal by this procedure, and some increase was noted in the amount of ferritin in bone-marrow. Storage and transport of $\mathrm{Fe}$ are therefore able to proceed at tissue $\mathrm{Cu}$ concentrations which are too low to allow for release of $\mathrm{Fe}$ from ferritin in the liver.

Slices of liver incubated anaerobically have been shown to liberate more $\mathrm{Fe}$ into the medium than similar slices incubated aerobically (Mazur, Baez \& Shorr, I955). The amount of $\mathrm{Fe}$ released into the medium during anaerobic incubation of liver slices from both deficient and normal rats, less than released during aerobic incubation, was related more closely to the total $\mathrm{Fe}$ content of the liver than to the $\mathrm{Cu}$ 
content (Table 5), in contradistinction to conditions in vivo where $\mathrm{Fe}$ is apparently not released when the $\mathrm{Cu}$ concentration is limiting. Results of experiments carried out in vitro are thus not always directly applicable to reactions occurring in the live animal.

The results presented suggest that a primary function of $\mathrm{Cu}$ in the metabolism of $\mathrm{Fe}$ is participation, either as a Cu-containing enzyme or as a co-factor in an enzyme system, in the reaction by which $\mathrm{Fe}$ is released from ferritin. This hypothesis is based on the assumption that $\mathrm{Fe}$ absorbed from the intestinal tract, and that injected intraperitoneally, is transported to the liver by transferrin.

The very large stores of $\mathrm{Fe}$ found in the livers of Cu-deficient sheep (Marston, 1952) and the apparent ease with which intraperitoneally injected $\mathrm{Fe}$ found its way to the livers (Table 6), and some to the bone-marrows, of rats given a diet deficient in both $\mathrm{Cu}$ and $\mathrm{Fe}$, together with the low haemoglobin and plasma $\mathrm{Fe}$ concentrations of these animals, makes the postulate of Osaki et al. (1966), that caeruloplasmin mediates in the mechanism by which $\mathrm{Fe}$ is attached to apotransferrin, difficult to accept if absorbed $\mathrm{Fe}$ is in fact transported by transferrin. If, on the other hand, transport of absorbed Fe is effected by a complex other than transferrin, which seems unlikely, though it is doubtful if there is any proof that it is not so, and transferrin is active only in the transport of Fe from storage sites such as liver and spleen to tissues where it is required, then a virtual absence of caeruloplasmin could explain the non-availability of $\mathrm{Fe}$, i.e. the reduction in plasma $\mathrm{Fe}$ (transferrin) concentrations in $\mathrm{Cu}$-deficient animals.

Whether $\mathrm{Cu}$ also assumes a role in the utilization of $\mathrm{Fe}$ for production of haemoglobin has not been determined. 6-Aminolaevulic acid dehydrase, which catalyses the formation of porphobilinogen, was originally thought to be a Cu-containing enzyme, but recent findings do not support this claim (cf. Rimington, 1958; Harris, 1963), and abnormally high concentrations of free protoporphyrin have been found in the red cells of $\mathrm{Cu}$-deficient sheep (Allen, 1956). The enzyme, ferrochelatase, which catalyses the production of haem from protoporphyrin and $\mathrm{Fe}$, is said to be inhibited by $\mathrm{Cu}$ (Labbe \& Hubbard, 196r).

The studies reported leave many questions unanswered; they do, however, indicate fields where further study may be profitably undertaken.

Collection of blood from and perfusion of the rats of Expt I, and the copper analyses associated with Expt I were carried out by Mr D. W. Dewey. The help of Dr E. G. Holmes, formerly of the Division of Biochemistry and General Nutrition, CSIRO, and now at the Institute of Medical and Veterinary Science, Adelaide, who co-operated in some of the preliminary experiments, is gratefully acknowledged. The histopathological report was by courtesy of Dr J. A. Bonnin, Director of the Institute of Medical and Veterinary Science, Adelaide. Dr E. A. Cornish, Chief of the Division of Mathematical Statistics, CSIRO, kindly provided the statistical analyses. 


\section{REFERENCES}

Aisen, P., Aasa, R., Malmström, B. G. \& Vänngård, T. (1967). F. biol. Chem. 242, 2484.

Alfrey, C. P. Jr, Lynch, E. C. \& Whitley, C. E. (1967). F. Lab. clin. Med. 70, 419.

Allen, S. H. (1956). Biochem. F. 63, 46r.

Bates, G. W., Billups, C. \& Saltman, P. (1967a). J. biol. Chem. 242, 28 ro.

Bates, G. W., Billups, C. \& Saltman, P. (1967b). F. biol. Chem. 242, 2816.

Beutler, E., Fairbanks, V. F. \& Fahey, J. L. (1963). Clinical Disorders of Iron Metabolism. New York and London: Grune \& Stratton.

Billups, C., Pape, L. \& Saltman, P. (1967). F. biol. Chem. 242, 4284.

Brown, E. B. (1963). Am. F. clin. Nutr. 12, 205.

Cheney, B. A., Lothe, K., Morgan, E. H., Sood, S. K. \& Finch, C. A. (r967). Am. F. Physiol. $212,376$.

Coons, C. M. (1964). A. Rev. Biochem. 33, 459.

Crosby, W. H. \& Furth, F. W. (1956). Blood Ir, 380.

Dacie, J. V. \& Lewis, S. M. (1963). Practical Haematology 3 rd ed. London: J. \& A. Churchill Ltd.

Darcel, C. le Q. (196I). Can. F. comp. Med. $25,129$.

Deutsch, W. (1936). F. Physiol., Lond. 87, 56 P.

Dreosti, I. E. \& Quicke, G. V. (1968). Br. F. Nutr. 22, I.

Gabuzda, T. G. \& Pearson, J. (1968). Nature, Lond. 220, 1234.

Giovanniello, T. J. \& Peters, T. Jr (1963). Stand. Meth. clin. Chem. 4, 139.

Greenough, W. B. III, Peters, T. Jr \& Thomas, E. D. (1962). F. clin. Invest. 41, I I 6.

Gross, F. (editor) (I g64). Iron Metabolism. International Symposium, Aix-en-Provence, France, I963: sponsors Ciba.

Harris, J. W. (1963). The Red Cell. Cambridge, Massachusetts: Harvard University Press.

Hart, E. B., Steenbock, H., Waddell, J. \& Elvehjem, C. A. (1928). F. biol. Chem. 77, 797.

Hedenstedt, S. (1947). Acta chir. scand. 95, suppl. I28.

Labbe, R. F. \& Hubbard, N. (1961). Biochim. biophys. Acta 52, 130.

Marston, H. R. (1952). Physiol. Rev. 32, 66.

Marston, H. R. \& Allen, S. H. (1967). Nature, Lond. $215,645$.

Mazur, A., Baez, S. \& Shorr, E. (1955). F. biol. Chem. 213, I47.

Morgan, E. H. (1961). Aust. F. exp. Biol. med. Sci. 39, 37г.

Osaki, S., Johnson, D. A. \& Frieden, E. (1966) F. biol. Chem. 24r, 2746.

Pape, L., Multani, J. S., Stitt, C. \& Saltman, P. (1968a). Biochemistry, Easton 7, 606.

Pape, L., Multani, J. S., Stitt, C. \& Saltman, P. (I968b). Biochemistry, Easton 7, 613.

Reichlin, M. \& Harrington, W. J. (1960). Blood 16, 1298.

Reith, E. J. (196r). F. Cell Biol. 9, 825.

Rice, E. W. (1963). Stand. Meth. clin. Chem. 4, 57.

Rimington, C. (1958). Rev. pure appl. Chem. 8, 129.

Salera, U., Magnanelli, P., d'Avino, R., Zecca, I. \& Matcovich, A. L. (196r). Proc. 8th Congr. Eur. Soc. Haematol., Vienna p. 240a.

Smith, J. A., Drysdale, J. W., Goldberg, A. \& Munro, H. N. (1968). Br. F. Haemat. 14, 79.

Summerson, W. H. (1938). F. biol. Chem. 123, cxix.

Thirayothin, P. \& Crosby, W. H. (1962). F. clin. Invest. 4r, 1206.

Underwood, E. J. (1962). Trace Elements in Human and Animal Nutrition 2nd ed. New York and London: Academic Press Inc.

Wynter, C. V. A. \& Williams, R. (1968). Lancet ii, 534.

Zail, S. S., Charlton, R. W., Torrance, J. D. \& Bothwell, T. H. (1964). F. clin. Invest. 43, 670. 